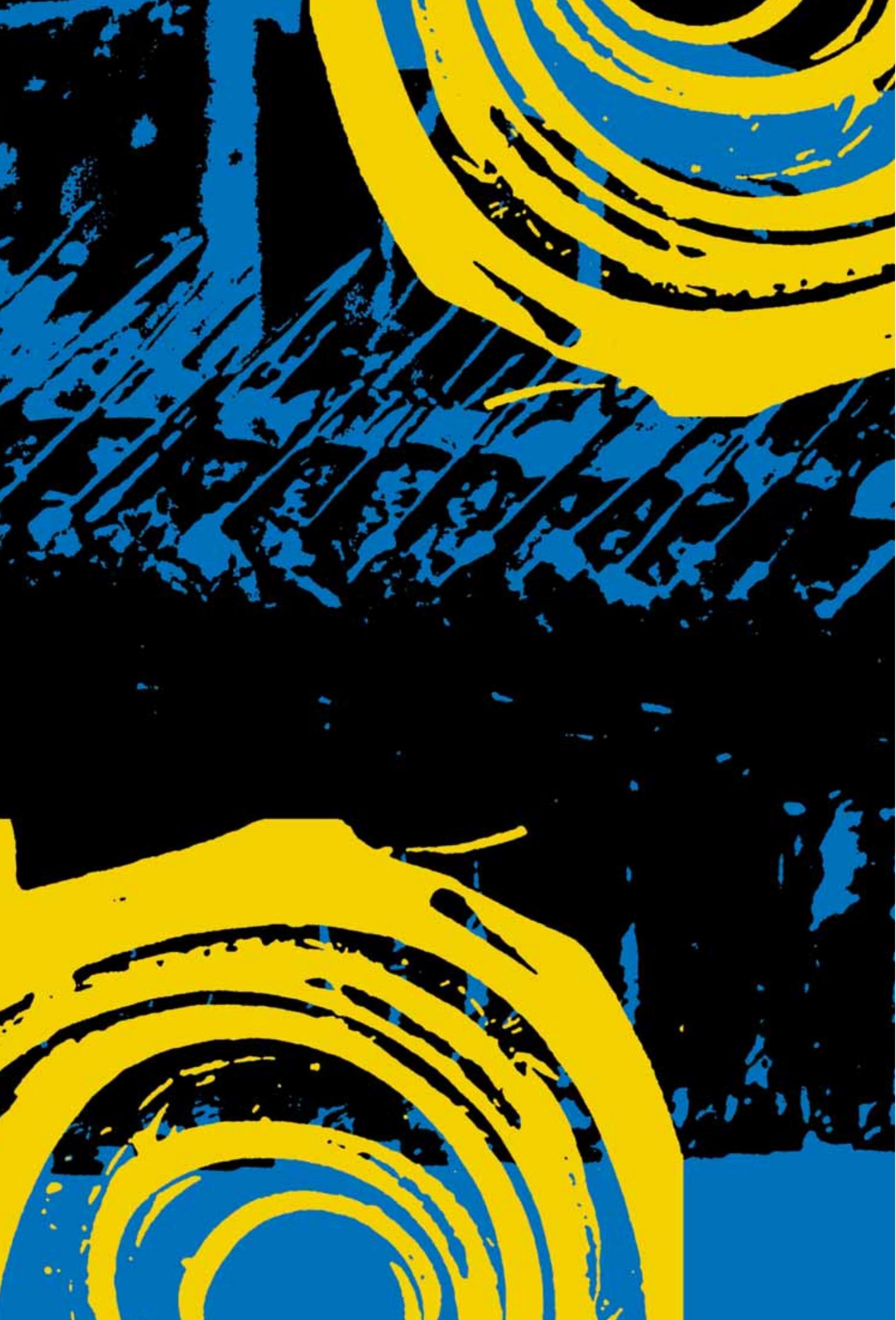




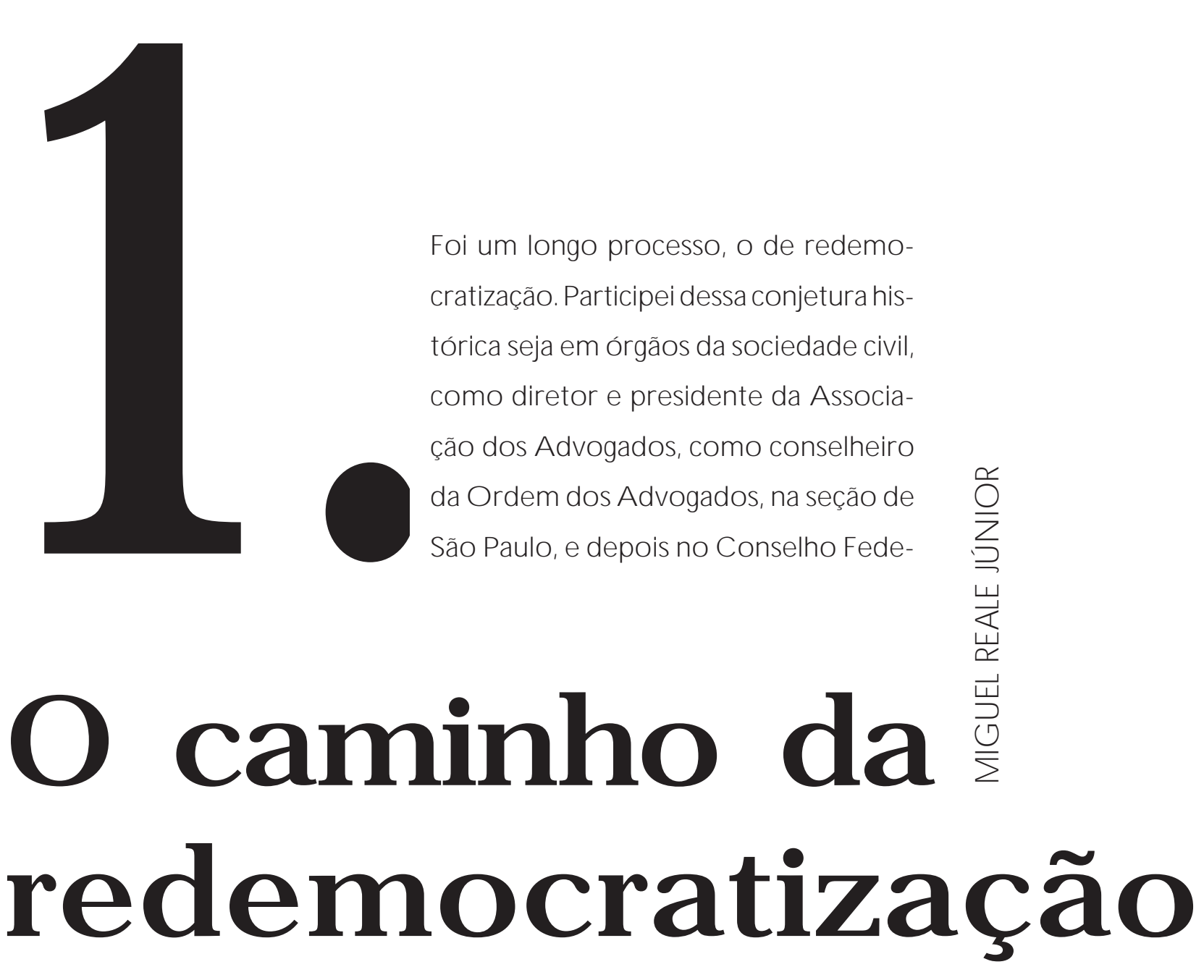

ral, seja como membro do PMD B e diretor da Fundação Pedroso Horta, instituição de estudos do partido. Seria difícil falar desses fatos sem tomar a ousadia de usar a primeira pessoa. Farei, então, com a condescendência do leitor, um relato acerca dos aco ntecimentos do squais diretamente participei.

2. A advocacia criminal levou-me a ter uma consciência MGUBREAE JÚNORéadhogadb, professortitularde DreitoPenal daFaaldade deDreitodaUPe atorde, entreatros, efetiva da importância da defesa da liberdade em todas as suas dimensões, em especial da liberdade do cidadão frente ao Estado autoritário.

Fo rmado em 1967, passara a advo gar na área criminal desde o quarto ano. Fo i de especial relevo a convivência 
com os advogados criminais, forjados na proteção do indivíduo no confronto com a repressão policial, muitas vezes desmedida e ilícita, com prisões para averiguação, flagrantes preparados, exigências de favores indevidos. O habeas corpus constituía o instrumento básico de trabalho na contenção do abuso de poder.

Por isso, a imediata revolta dos advogados, especialmente os criminais, com a edição do Ato Institucional no 5 de 13 de dezembro de 1968, que dentre outras medidas autoritárias vedava garantia do habeas corpus em crimes contra a segurança nacional e a economia popular. Nessa época convivia diariamente com advogados que se notabilizaram na defesa de presos políticos, como José Carlos Dias, Raymundo Paschoal Barbosa e tantos outros. Advoguei pouco na Justiça Militar.

Ficou marcada em meu espírito a defesa, a meu cargo, de Antonio Funari, advogado do líder estudantil Travassos, injustamente acusado de haver, na carceragem, passado informes ao cliente, como uma forma de aviltamento e de desprestígio da figura do advogado. Acompanhei, contudo, pari passu, as agruras da defesa de presos políticos, freqüentando, ao menos uma vez por semana, a Auditoria Militar, para acompanhar os julgamentos, principalmente sendo advogado José Carlos Dias.

3. Em 1972, passei a integrar o Conselho da Associação dos Advogados de São Paulo e fui diretor cultural da Associação. Foi nos idos de 1973 que me empenhei na luta contra a submissão da Ordem dos Advogados ao Ministério do Trabalho decretada pela ditadura. Fui, na condição de membro da Diretoria da Associação dos Advogados de São Paulo, a uma audiência com o então ministro da Justiça, Alfredo Buzaid. O ministro negou de início que soubesse da medida legal. Pediu para se localizar o processo no Ministério, no qual verificou existir mesmo um despacho seu favorável à matéria. Mostramos a contradição intransponível de se submeter o advogado que luta contra o Estado, em todos os seus níveis, ao pró- prio Estado. O ministro apenas disse que daria atenção ao problema.

A questão foi resolvida graças à tenacidade do batonnier federal José Ribeiro de Castro, que organizou uma coletânea de pareceres de juristas indicando a ilegalidade e ilegitimidade da subordinação da OAB ao Ministério do Trabalho, por suas características específicas, pois o exercício da advocacia não poderia ser objeto da atuação disciplinar ditada por uma OAB destituída de independência e autonomia, colocada em linha como entidade da Administração Direta. A ditadura sabia a quem devia silenciar para se manter, e os reclamos a serem emudecidos vinham em grande parte dos órgãos de classe dos advogados.

4. Quando assumi a presidência da Associação dos Advogados de São Paulo, com apoio do Conselho, encaminhei a entidade a ocupar a linha de frente na campanha pela

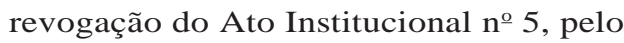
restabelecimento do habeas corpus, pela anistia, dentro do processo então denominado pelo governo Geisel de distensão.

A Associação passou a ser um celeiro de propostas, dentre as quais destaco a comissão instituída para apresentar críticas e sugestões à reforma constitucional proposta pelo Ministério da Justiça, então ocupado por Petrônio Portella. A comissão era composta por Goffredo da Silva Telles, Celso Bastos, Walter Ceneviva e outros. As sugestões da Associação apontavam no sentido do retorno da normalidade democrática e cuidavam em grande parte dos partidos políticos e do sistema eleitoral.

A Associação passou a dar guarida aos líderes políticos da oposição, pelo que organizou duas grandes reuniões para ouvir de uma feita Paulo Brossard, líder da oposição no Senado, e de outra Teotônio Villela, em especial analisando as conseqüências nefastas de se perenizar a dominação política da ditadura por via do pacote de abril de 1977. Com essa atividade a Associação dos Advogados de São Paulo ocupava, cada vez mais, espaços na imprensa, na qual continuamente se reivindicavam avanços no processo de redemocratização. 


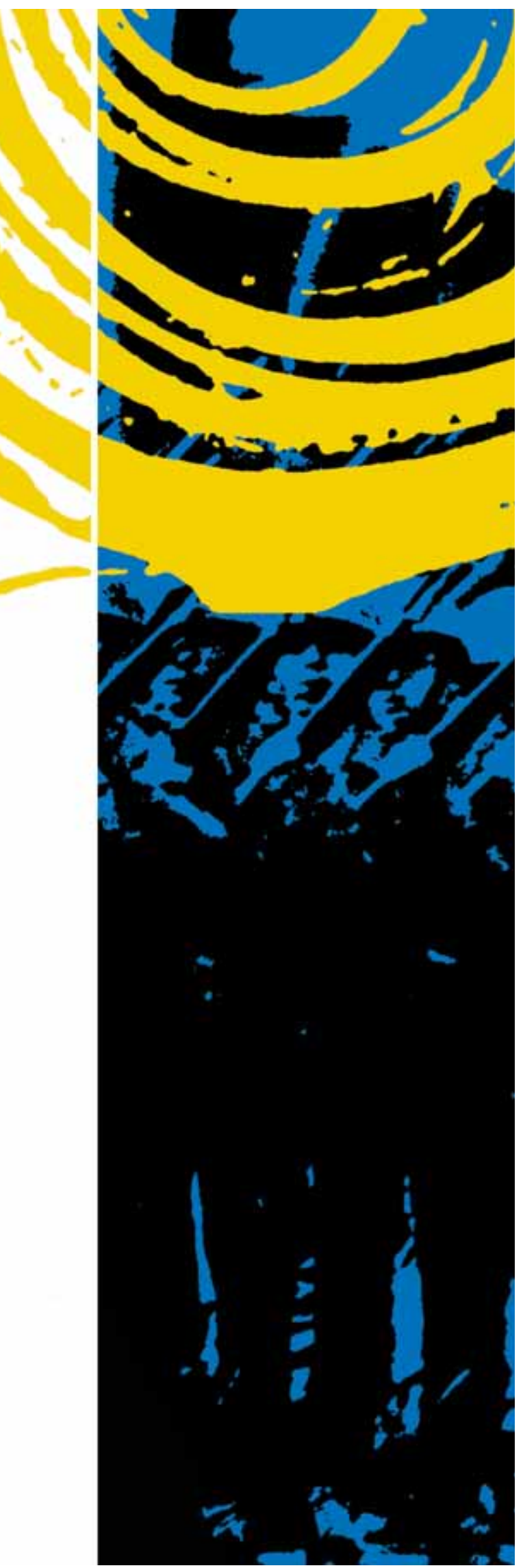

A Associação dos Advogados de São Paulo, contrariando a tradição de não se manifestar em matéria política, foi a primeira entidade a subscrever a Carta aos Brasileiros em 1977, com a compreensão de que não se tratava de questão políticopartidária, mas institucional.

Relevante foi a Conferência Nacional da Ordem dos Advogados em junho de 1978, em Curitiba, que tinha por tema central o Estado de direito. Participei como palestrante na qualidade de presidente da Associação dos Advogados, falando sobre o tema "Tecnoburocracia e Estado de direito". Mas o relevante foi o confronto liderado por São Paulo, tendo-se à frente Goffredo da Silva Telles, em face da tendência pretendida pela direção da Ordem no sentido de se aceitar o gradualismo no processo de redemocratização. Nós nos opúnhamos a essa linha defendida principalmente pelo então advogado Oscar Dias Corrêa, pois para nós não havia meia liberdade política, nem a democracia deveria ser apenas a possível, mas sim a democracia sem adjetivos. Nossa tese prevaleceu e foram rejeitadas em plenário as teses gradualistas, tão desejadas por Petrônio Portella.

5. A anistia passou a ser a questão essencial. Apresentado o projeto de lei da anistia em 1979, já findo o meu mandato de presidente da Associação dos Advogados, passei a ocupar a representação de São Paulo no Conselho Federal da Ordem, e nessa condição vim a efetivar, em nome da Ordem, juntamente com José de Castro Bigi, emendas ao projeto de anistia, que foram apresentadas por parlamentares do MDB. Em nossas propostas nos opúnhamos ao tratamento diferenciado, concedendo-se anistia aos que teriam cometido crimes conexos, eufemismo usado pelo regime para se referir aos crimes praticados por militares e policiais agentes da tortura e da morte de presos políticos, sem que de outro lado se estendesse a anistia aos que haviam participado da luta armada contra a ditadura.

A anistia deveria ser uma estrada de mão dupla se o argumento para se anistiar os torturadores era o da pacificação nacional. 
Creio que obtivemos bom resultado nessa empreitada, especialmente graças à interpretação dada à lei pelo Tribunal Superior Militar.

6. Em 1980, restabelecido o pluripartidarismo, fui convidado por Mario Covas, presidente do PMDB de São Paulo, que sucedia ao MDB, para integrar o partido, participando da direção da Fundação Pedroso Horta. Passava da militância em órgãos da sociedade civil para a atuação em instituição política, no PMDB.

7. A partir desse momento estreitaram-se as relações com dois homens fundamentais no processo de redemocratização: Ulysses Guimarães e Franco Montoro. Fui o advogado do partido nas eleições para governador em 1982 e tivemos de enfrentar a máquina malufista e suas artimanhas, como o panfleto "Cavalo de Tróia”, acusando Montoro de trazer escondido no seu bojo os comunistas, anarquistas, etc.

Em 1983, com a vitória nas eleições, vim a ser assessor especial do governador Montoro e presidente em exercício da Fundação Pedroso Horta. Desde 1980, freqüentava semanalmente a casa do dr. Ulysses, especialmente nas reuniões de domingo à noite para discussão de temas nacionais. Quero lembrar, então, dois fatos vividos em torno da campanha por eleições diretas, um com o dr. Ulysses, outro com o governador Montoro.

8. Muito se fala sobre qual teria sido a primeira manifestação pública em favor das eleições diretas. Quero trazer à tona, então, fatos que restam esquecidos, pois antes mesmo da reunião de governadores em 15 de outubro de 1983 em Foz do Iguaçu, para planejar a estratégia da campanha das diretas, encontro esse cuja finalidade política foi disfarçada em debate sobre rumos da economia com a presença dos secretários da Fazenda, houve uma reunião pública em 1ำ de outubro, no plenário da Assembléia Legislativa de São Paulo.

Em junho de 1983, passei a ser o presidente de fato da Fundação Pedroso Horta e

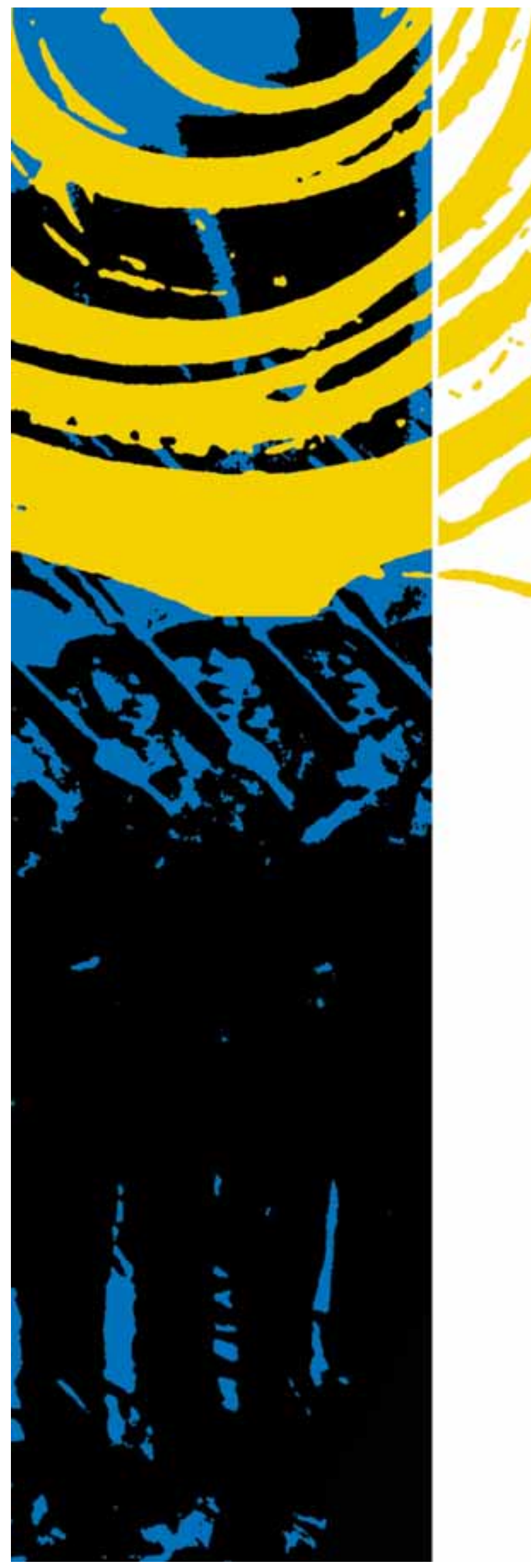


nessa condição fui chamado por dr. Ulysses, que pretendia realizar em agosto um ato público em favor das eleições diretas. Ulysses ficou doente, Teotônio Villela assumiu a presidência do partido. Após retiro em uma fazenda em Araçatuba, já agosto retomaram-se as conversas sobre o ato a se realizar tendo por tema as eleições diretas. Dizia-se que Ulysses estava em sua agonia política, mas ressurgindo, tal como Fênix das cinzas, Ulysses, em agosto chamoume novamente à sua residência e pretendia realizar um encontro de envergadura nacional reivindicando eleições diretas e outras questões de cunho econômico.

Como era de seu feitio, foi anotando em folha de bloco de notas da Câmara dos Deputados os planos a serem implementados, e cujo fac-símile encontra-se publicado na revista Economie et Culture no 11 (junho-agosto de 1994,p. 37). Nessa folha pode-se ver anotado, nas garatujas do dr. Ulysses, os seguintes dados: "dia 18 (sexta) de setembro. Local: 10.000 pessoas. Temas: eleições diretas, moratória, desemprego, dia 18 sexta, 19 sábado, 20 domingo, encerramento".

O dr. Ulysses assinalou, também, as pessoas que deveriam estar presentes: Dante de Oliveira, presidente nacional (Ulysses), presidente regional (Fernando Henrique), Montoro, presidente da UNE, líder operário, presidente Henrique Santillo (presidia em nível nacional a Fundação Pedroso Horta). Anotava também que deveria haver movimentação de caravanas do interior e de outros estados.

Guardei esse papel de notas, no qual ficaram registradas, com minha letra, outras presenças a serem providenciadas, bem como o nome dos participantes de debate econômico que deveria ocorrer. Estão assinalados os seguintes nomes: empresários, Antonio Ermírio e Bardella; líderes coordenadores dos debates, Freitas e Máximo. H. Lucena coordena o encerramento. Celso Furtado, Belluzzo, João Manoel, José Serra, Conceição, Lessa. Secretários de Planejamento: São Paulo, Minas, Paraná.

Comecei a procurar local para a manifestação: inicialmente o Pacaembuzinho, com capacidade para 2.000 pessoas; depois, pensando em número maior de participantes, o salão do clube Pinheiros, para 5.000 pessoas e, por fim, o estádio do Palmeiras para 10.000 pessoas.

Optou-se afinal, com receio de uma vinda de público reduzida, por convocar a manifestação para o plenário da Assembléia Legislativa de São Paulo. Uma carta oficial do partido, assinada por Ulysses, presidente nacional, Fernando Henrique Cardoso, presidente regional, e por mim, como diretor da Fundação Pedroso Horta, foi enviada a todos os membros do partido, convocando para participarem do Encontro "Fala Brasil", em favor das eleições diretas e contra os rumos da economia nacional.

A carta, por mim escrita e discutida com os principais signatários (fac-símile igualmente publicado na revista Economie et Culture), tinha o seguinte teor:

\section{"Fala Brasil}

O PMDB lançou o grito Basta, legitimado por 20 milhões de votos recebidos em todos os Estados da Federação nas últimas eleições:

Basta ao Decreto 2.045 [que reduzia a correção salarial]

Basta ao desemprego

Basta à crise e à recessão

Basta de FMI

Em primeiro de outubro às 15 horas no Plenário da Assembléia Legislativa do Estado de São Paulo, a direção nacional e regional do PMDB, juntamente com a Fundação Pedroso Horta promoverão o Encontro 'Fala Brasil' ao qual comparecerão as lideranças partidárias reivindicando: eleições diretas; moratória; retomada do crescimento; restabelecimento do mercado interno.

Em 2 de outubro, às 15 horas, também na Assembléia Legislativa a saída para a crise econômica será debatida por Celso Furtado, João Manuel Cardoso de Mello, José 
Serra, Luciano Coutinho, Paulo Renato de Souza".

Em meados de setembro, assumira o cargo de secretário da Segurança Pública, mas continuei a me encarregar da organização do evento.

No dia $1^{\circ}$ de outubro fui a um almoço na casa do senador Severo Gomes, no qual estavam presentes os governadores Tancredo Neves, José Richa, bem como os senadores Pedro Simon e Humberto Lucena. Lá se ponderava acerca da necessidade de logo se reunirem os governadores para planejar a campanha das diretas, o que sucedeu quinze dias depois em Foz do Iguaçu. Fomos todos, terminado o almoço, para o ato na Assembléia Legislativa.

No meio da tarde, por volta das 16 horas, teve início o encontro que reuniu efetivamente as lideranças partidárias e alguns líderes da sociedade civil. Nessa reunião lançou-se um grito pelas eleições diretas, mas a presença de público foi um fracasso, não havia, tirando os próceres partidários, mais de cem pessoas.

Comentei com o dr. Ulysses, na ocasião, o meu desapontamento com a presença tão diminuta de pessoas, mesmo após a convocatória enviada, mas Ulysses, com seus vivos olhos azuis brilhando, sorriu e apenas me disse: "Encontramos o filão, estamos no bom caminho”. Percebi que estava diante de um visionário que via o que eu não via e no qual era preciso acreditar.

No dia 2 de outubro, houve a reunião dos economistas para discutir a saída da crise econômica. Revelava-se uma intensa preocupação com a compressão salarial e a urgência na retomada do crescimento e do emprego, diante da recessão que se iniciara em 1981.

No decorrer de outubro e novembro, além da mencionada reunião de Foz do Iguaçu, houve duas manifestações públicas organizadas pelos governadores de Goiás, Íris Resende, e do Paraná, José Richa, com grande número de pessoas. Em 15 de novembro ocorreu um comício em frente ao estádio do Pacaembu, em São Paulo, promovido pelo PT.
9. No início de janeiro de 1984, o governador Montoro chamou vários secretários para uma reunião, afirmando que pretendia promover um grande comício pelas diretas no dia 25 de janeiro, aniversário da cidade de São Paulo, feriado. Coube à Secretaria da Segurança organizar o evento. Já haviam ocorrido duas reuniões na Praça da Sé no semestre anterior, sobre as quais falarei a seguir, mas que constituíam experiências importantes no preparo logístico do comício do dia 25 de janeiro.

Determinei que se avaliasse a capacidade da Praça da Sé, concluindo-se, segundo os metros quadrados da praça em seu setor central, sem ocupação das ruas que a contornam, que cabiam cerca de 50.000 pessoas. Temi que, em face do fracasso da reunião de $1^{\circ}$ de outubro, não se chegasse a encher sequer esse setor central. Um grupo de oficiais da PM foi a Curitiba para se inteirar de como fora a organização e o desenvolvimento do comício de Curitiba. Aos que alertavam para a possibilidade de fracasso da reunião, o governador Montoro, com seu entusiasmo e otimismo natural, respondia que o dia 25 mostraria quem estava certo. Ele estava certo. Mais de 300.000 pessoas foram à Praça da Sé.

Inúmeras medidas preventivas foram tomadas e instalei uma central de controle da manifestação no gabinete da Secretaria da Segurança, no qual me mantive a maior parte do tempo, apenas passando rapidamente pelo comício. No final da tarde estive no Palácio dos Bandeirantes e os governadores falavam com apreço da organização do evento, transcorrido sem incidentes que o tisnassem. Foi uma grande vitória da sociedade civil e dos partidos de oposição, mormente do PMDB. Mas o grande vitorioso foi sem dúvida o governador Montoro.

Na semana seguinte, pedi exoneração do cargo de secretário da Segurança Pública, que não se amoldava inteiramente ao meu perfil, apesar de possuir naquele instante o necessário respaldo das duas corporações, Polícia Civil e Militar.

10. Atrás mencionei duas manifestações que ocorreram em outubro e novembro de 
1983 na Praça da Sé. A primeira delas foi a denominada “Tarde da Oração", promovida pela Igreja sob a liderança do cardeal Arns, para rezar pelos assalariados empobrecidos e protestar contra o arrocho salarial promovido pelo governo federal, por meio do Decreto no 2.045 .

Por solicitação do governador Montoro, estive na sede do II Exército para parlamentar com o então comandante, general Sérgio Ary Pires, que se antepunha radicalmente à manifestação, solicitando que eu, como secretário da Segurança, não autorizasse a reunião. Antepus-me ao solicitado pelo general, que me responsabilizou pelo que poderia acontecer, debitando em minhas costas qualquer incidente grave.

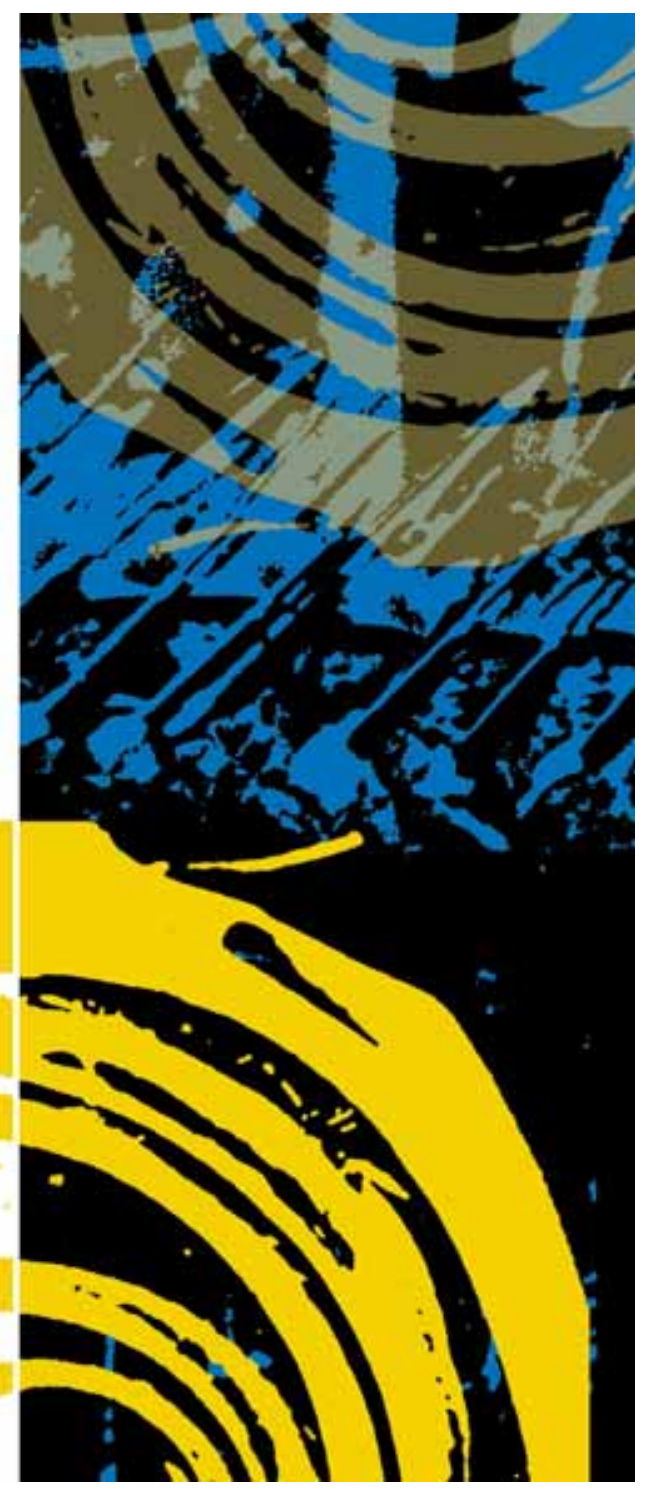

Após comunicar o governador do confronto estabelecido, com sua aprovação, tomei imediatas providências para inviabilizar qualquer fato negativo. Oficiais e delegados do meu gabinete mantiveram contato com o padre Dario da catedral da Sé, visto por alguns oficiais como esquerdista, para organizarem com a Igreja a manifestação. Policiais engalanados formaram a guarda de honra em torno do altar, policiais femininos instalaram-se dentro da catedral. Um ônibus-hospital ficou posicionado na rua lateral. Policiais civis se introduziram em meio aos fiéis para controlar atitudes eventualmente suspeitas. Passei uma tarde de cão, à espera de notícias da Praça da Sé. O ato transcorreu em perfeita tranqüilidade. Imediatamente liguei, eufórico por dentro, para o general comandante do II Exército.

A Polícia Militar deixara de reprimir atos públicos de protesto contra o governo da ditadura, para, ao contrário, protegê-los, e até mesmo auxiliar na organização. Era uma mudança de mentalidade.

Outra manifestação ocorreria na Praça da Sé. Agora convocada pelo Sindicato dos Metalúrgicos. Fui novamente convidado a parlamentar com o comandante do II Exército. Seria a reunião pública em um dia da semana, às 18 horas. O general pedia que não autorizasse o comício, especialmente argumentando que a hora marcada envolveria pessoas de retorno para casa, que seriam a contragosto imiscuídas na "agitação", e a possibilidade de conturbação da ordem pública era grande. Contestei o general, mas me comprometi a falar com as lideranças sindicais para transferir a manifestação para as 19 horas.

Tive, com a intermediação do secretário do Trabalho, Almir Pazzianoto, encontros sigilosos com o Joaquinzão e Luis Antônio Medeiros, respectivamente presidente e secretário do Sindicato dos Metalúrgicos. Foram dois encontros sigilosos, a pedido dos sindicalistas, pois os trabalhadores, com o vezo da ditadura, jamais entenderiam que se encontrassem com o secretário da Segurança. Erasmo Dias deixara marcas. 
Foi, então, acertado que o comício seria às 19 horas. O mesmo esquema de segurança da "Tarde da Oração" foi montado, com um curioso acréscimo: oficiais da Polícia Militar mantiveram entendimentos com os "seguranças" do Sindicato dos Metalúrgicos, para em conjunto cuidarem das medidas preventivas e da ordem no transcorrer do ato. Nada além dos protestos contra o arrocho salarial e a ditadura ocorreu naquele início de noite na Praça da Sé. De novo liguei para o comandante do II Exército.

A Polícia Militar inaugurava, como fez também durante as greves, no período em que fui secretário, uma nova postura frente aos trabalhadores: acompanhar e colaborar para a ordem das manifestações, e não reprimi-las. O mesmo se deu na gestão de Michel Temer, durante o governo Montoro.

11. Perdida a batalha da Emenda Dante de Oliveira, das eleições diretas restava o dilema: disputar ou não a eleição no Colégio Eleitoral. Ter uma conduta pautada pela mais exata fidelidade ao princípio de que a legitimidade só advém da eleição direta, ou entrar no jogo e tentar vencer a ditadura segundo suas próprias regras. Para discutir essa questão houve, em um domingo à noite, reunião mais ampla do que a habitual, na casa do dr. Ulysses.

O grupo dividiu-se. Ulysses só ouvia, como sempre, sem opinar, só registrando. Venceu a idéia, por maioria estreita, de se ir ao Colégio Eleitoral e disputar a eleição. Lembro que me manifestei a favor da ida ao Colégio Eleitoral, argumentando que a recusa em ter um candidato, naquele momento em que o país já estava mobilizado contra o regime, seria asfaltar a estrada do Maluf. No sentido de apresentar candidato no Colégio Eleitoral manifestaram-se, entre outros, Aberto Goldman, Almir Pazzianotto, Fernando Gasparian.

12. Um último fato peço licença para recordar, a revelar como a ditadura já nos seus estertores ainda podia atemorizar. Não me recordo da data exata, mas cerca de um mês antes da eleição pelo Colégio Eleito- ral, meu pai fora a Brasília, onde se entrevistara com o ministro Leitão de Abreu, que lhe confidenciara sua preocupação com a possibilidade de um golpe militar que estaria sendo urdido nos quadros do SNI. Ao chegar de Brasília, meu pai pediu-me para jantar em sua casa e contou-me sua apreensão com o revelado por Leitão de Abreu.

Liguei, então, para o deputado Flávio Bierrenbach, pedindo que nos encontrássemos em minha casa, pois tinha uma revelação importante a fazer. Ao saber das notícias, Flávio Bierrenbach achou conveniente irmos à casa de Fernando Henrique, que depois de se inteirar dos fatos ligou

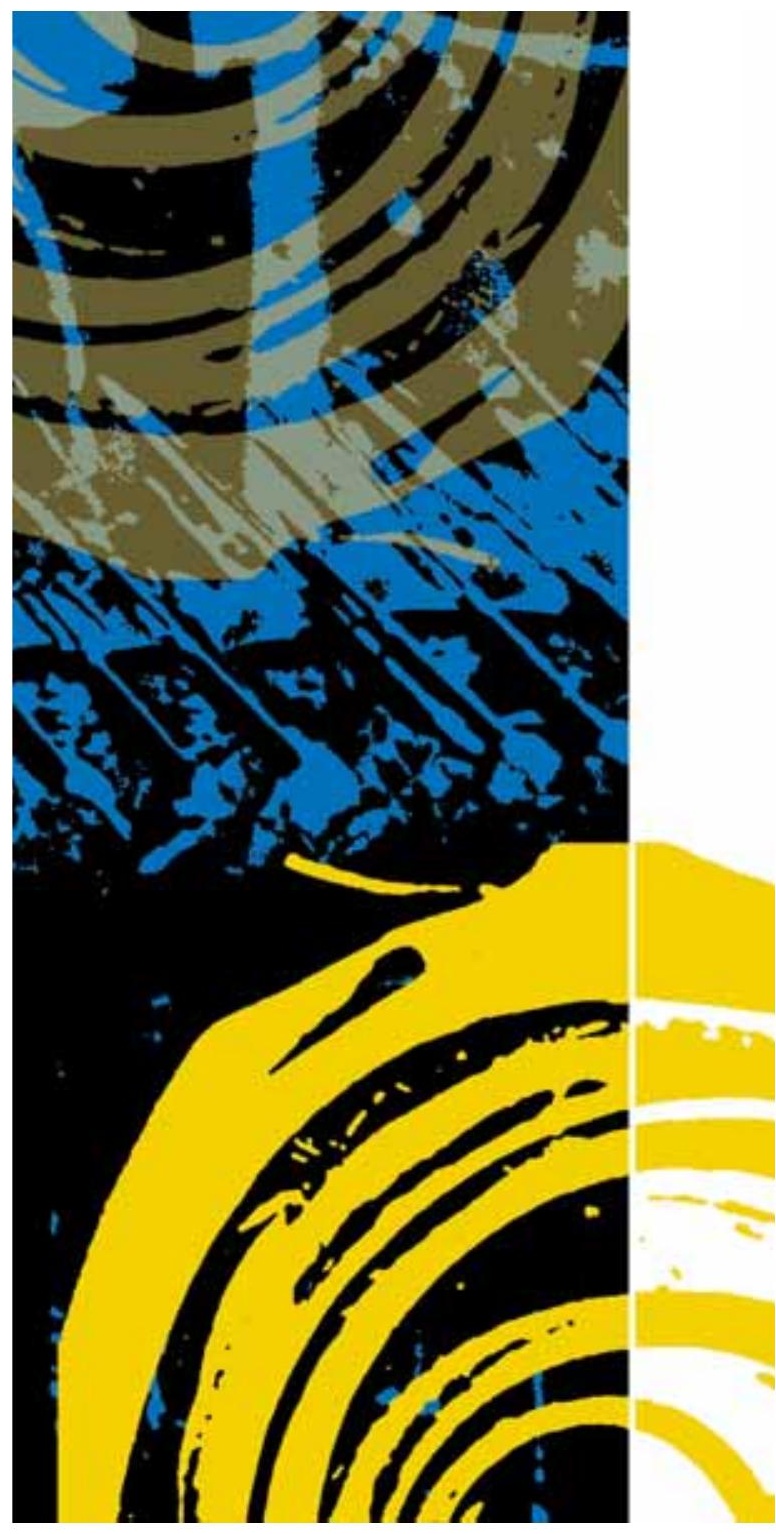


para Roberto Gusmão, secretário de Governo de São Paulo e em contínuo contato com Tancredo. Dirigimo-nos, então, os três, para a casa de Roberto Gusmão, onde foram avaliadas as informações e concluiuse que Gusmão daria notícias na manhã seguinte a Montoro e Tancredo.

Foram, a partir do dia seguinte, feitos contatos com setores militares, ficando eu incumbido de solicitar o apoio das polícias paulistas, em especial da Polícia Militar, para planejar, até mesmo, uma rota de fuga para Tancredo. A história indica que todos os movimentos sediciosos tiveram definitivo e importante respaldo na Polícia Militar, seja de Minas, de São Paulo ou do Rio Grande do Sul. Era fundamental ter a certeza do respaldo da Polícia Militar de São Paulo. Dei ciência dos fatos ao secretário da Segurança Pública, Michel Temer, a quem comuniquei que iria entrar em contato com os chefes de ambas as polícias, que puseram suas corporações em absoluto apoio a Tancredo.

Acompanhei o comandante da Polícia Militar a um encontro em escritório que Tancredo mantinha em São Paulo no bairro do Itaim, mas o contato foi apenas com Roberto Gusmão, encarregando-se a Polícia Militar do planejamento de ações de proteção a Tancredo.

Nada ocorreu, como se sabe. O Brasil foi vítima, no entanto, de um duro golpe do destino que impediu termos Tancredo como presidente. Com imensos percalços, há vinte anos alcançava-se a normalidade democrática, consolidada na nova Constituição de 1988.

13. O regime militar buscou decretar a tutela do Estado sobre a sociedade brasileira. O Estado tecnoburocrático partia da presunção de que o cordial povo brasileiro precisaria, em sua ingenuidade, ser protegido contra ideologias exóticas alienígenas, em descompasso com as nossas tradições cristãs.

No autoritarismo, no entanto, polarizouse o confronto, malgrado a intenção dos detentores do poder fosse, em uma visão funcionalista da sociedade, suprimir os antagonismos para instituir uma estabilidade e unanimidade cinzentas. Pelo contrário, foi no autoritarismo que vicejou o fortalecimento da sociedade civil e se fez presente o pluralismo social denunciando a mentira do consenso apresentado pela ditadura. O pluralismo social estava vigendo por via de organizações da sociedade civil, entidades de classe, profissionais ou econômicas, estudantis, as igrejas, instituições culturais diversas. Essas forças sociais organizadas não se limitaram a promover reivindicações em favor de seus interesses imediatos e diretos, mas, com consciência de cidadania, afrontaram o centralismo político autoritário.

Sem a sociedade civil, sabe-se, o partido e os políticos de oposição não derrotariam a ditadura. Restaurada a democracia, restabelecidos os canais normais de manifestação política, o papel políticoinstitucional das organizações da sociedade civil reduziu-se, como, aliás, deveria mesmo suceder.

14. Por fim, cabe ressaltar que na convocação da reunião idealizada por Ulysses o tema das eleições diretas casava-se com a discussão sobre a crise econômica. Ao lado da luta pela cidadania política, havia a reivindicação de retomada do crescimento, fim do desemprego, criação de um mercado interno, com vistas à justiça social.

Caminhamos na raia da liberdade política, mas a organização política ainda deita raízes na estrutura pensada em 1946, no que tange ao sistema eleitoral e partidário. Nesse campo nada avançamos. Na raia da justiça social a defasagem é ainda maior: retomada do crescimento, desemprego, criação de um mercado interno são temas tão atuais como eram no início da década de 80 , em plena ditadura.

Outros fatos poderiam ser lembrados, mas creio que o mais relevante foi trazido à baila, suficiente para provocar uma meditação sobre o vivido, as esperanças depositadas, bem como acerca dos objetivos alcançados e das decepções colhidas no decorrer do tempo, nesses vinte anos de democracia no Brasil. 